\title{
Mason-Pfizer Monkey Virus
}

National Cancer Institute

\section{Source}

National Cancer Institute. Mason-Pfizer Monkey Virus. NCI Thesaurus. Code C14236.

Mason-Pfizer Monkey Virus; causes AIDS-like disease ( $\mathrm{NCl})$ 